\title{
TARJIH SEBAGAI METODE: PERSPEKTIF USUL FIQH
}

\section{Imron Rosyadi}

\author{
Dosen Program Studi Hukum Ekonomi Syariah \\ Fakultas Agama Islam \\ Universitas Muhammadiyah Jakarta \\ e-mail: Imron.Rosyadi@ums.ac.id
}

\begin{abstract}
Abstrak: Tulisan singkat ini tidak mencoba membahas keempat solusi di atas tetapi hanya ingin menjelaskan posisi tarjih sebagai metode untuk menyelesaikan suatu dalil atau pendapat yang tanpak saling bertentangan. Indikator perumusan suatu pendapat dengan menggunakan metode tarjih adalah pengungkapan pendapat-pendapat dengan argumentasi masing-masing lalu dari sekalian pendapat itu ditelusuri argument masing-masing. Setelah itu dipilih argument yang paling kuat di antara argument-argumen yang ada. Dalam studi ilmu ushul fiqh, tarjih ini merupakan solusi ketiga setelah metode al-jam'u wa taufiq dan nâsikh wa al-mansûkh. Para ulama usul fiqh telah memberikan berberapa persyaratan dalam menerapkan tarjih sebagai metode dalam merumuskan suatu masalah atau kasus.
\end{abstract}

Kata Kunci: Metode, Tarjih, Usul Fiqh

\section{Pendahuluan}

Dalam studi usul fiqh dikenal empat solusi untuk menyelesaikan dalil yang saling bertentangan (ta'âruḍ al-adillah). Empat solusi itu adalah al-jam'u wa at-taufiq (kompromi), nâsikh wa al-mansûkh, tarjih, dan tawaqquf. Keempatnya ini merupakan solusi secara herarkhis jika seseorang menemui dalil yang saling bertentangan. Dimulai dari al-jam'u wa at-taufíq tapi jika cara ini tidak dapat dilakukan maka baru solusi berikutnya, yaitu solusi nâsikh wa al-mansûkh. Jika solusi kedua tidak bisa ditempuh maka dipilih solusi ketiga, dan seterusnya.

Keempat solusi yang ditawarkan oleh ulama ushul fiqh di atas terhadap dalil yang saling bertentangan, meski tidak disebut secara khusus terhadap dalil yang mana, namun kalau dicermati, empat soslusi tersebut adalah untuk dalil yang berasal dari hadis atau untuk berbagai pemikiran yang berbeda. Hal ini oleh karena tidak mungkin al-Quran itu ayat-ayatnya saling bertentangan.

Sebagaimana diketahui bahwa dalil dalam studi usul fiqh meliputi dalil yang disepakati, misalnya al-Quran dan hadis maupun dalil yang tidak disepakati oleh mereka para ahli usul fiqh, seperti qiyas, ijma', istihsan, maslahah mursalah, dan sebagainya. Di samping dalil, yang termasuk sasaran objek kajian tarjih sebagai metode adalah mengkaji tentang pendapat-pendapat ulama' yang berbeda dengan cara memilih atau menguatkan salah satu dari ragam pendapat atau pemikiran dengan menelusuri argument yang paling kuat. Pendapat yang memiliki argument yang kuat itulah yang dipilih untuk dijadikan pedoman dalam beramal atau berislam.

Tulisan singkat ini tidak mencoba membahas keempat solusi di atas tetapi hanya ingin menjelaskan posisi tarjih sebagai metode untuk menyelesaikan suatu dalil atau pendapat yang tanpak saling bertentangan. Posisi tarjih sebagai metode dalam studi hukum Islam termasuk sering digunakan oleh para ulama di dalam penyelesaian suatu permasalahan.

\section{Tarjih: Perspektif Ulama Ushul}

Secara bahasa, kata at-tarjîh berasal dari akar kata (kata dasar) $r-j-h$ yang kemudian diikutkan wazan fa "ala (dobel 'ain) sehingga menjadi rajjaha-yurajjihu- 
tarjîh, yang memiliki arti memberikan penguatan kepada yang lain sehingga menjadi kuat. ${ }^{1}$ Menurut Muḥammad Wafâ, tarjîh secara bahasa adalah mengunggulkan sesuatu dengan lebih condong padanya dan memenangkannya. ${ }^{2}$ Adapun secara istilah, menurut Fakhr ad-Dîn ar-Râzî, seperti dikutip oleh asy-Syaukânî, bahwa tarjîh adalah menguatkan salah satu dari dua dalil atau pendapat agar diketahui dalil yang lebih kuat untuk diamalkan dan dalil yang lainnya dibuang (taqwiyah aḥad aț-țarîqaini 'alâ alâkhar li yu 'lama fa yu 'mala bih wa yutraka al-âkhar). ${ }^{3} \quad$ Menurut 'Alî Hasaballah, tarjîh secara istilah adalah menampakkan kelebihan salah satu dari dua dalil yang sama dengan sesuatu yang menjadikannya lebih utama untuk dipertimbangkan daripada yang lain. ${ }^{4}$ Menurut al-Baiḍâwî, tarjîh adalah menguatkan salah satu dalil dari dua dalil untuk diamalkannya (taqwiyah iḥdâ al-amâratain li yu'mala bihâ). ${ }^{5}$ Dengan kata lain, tarjịh adalah memilih salah satu pendapat atau dalil dari dua atau lebih dengan cara menampakkan kelebihan atau yang lebih kuat dari yang lainnya untuk selanjutnya diamalkan.

Dalam konsep usul fikih, tampaknya dalil-dalil yang hendak di-tarjîh ini secara lahiriyah dianggap memiliki kontradiksi satu dengan lainnya. Kontradiksi (ta'ârud al-adillah) ini kebanyakan berangkat dari hasil pemahaman atas dalil itu sendiri sehingga sebetulnya kontradiksi (ta'ârud al-adillah) itu bersifat lahiriyah semata. Meskipun kebanyakan bersifat lahiriyah namun ada juga kontradiksi di antara dalildalil itu secara hakiki. Karena itu, jika menemukan dua dalil yang kontradiktif baik secara lahiriyah maupun hakiki maka bisa dilakukan penyelesaiannya dengan tarjîh. Dengan kata lain, tarjîh ini dipilih sebagai cara untuk melakukan pilihan di antara dua dalil atau lebih yang kontradiktif setelah terlebih dahulu tidak mungkin untuk dilakukan kompromi (al-jam 'u wa at-taufíq) antara keduanya.

Ta 'âruḍ al-adillah itu terjadi pada dua atau lebih dalil hukum Islam. Ada tiga tempat yang dimungkinkan terjadinya ta ârud aladillah, pertama: antara dalil qaț 'î dengan dalil żannî. Tempat Ta'ârud al-adillah yang pertama ini memang masih menjadi perdebatan di kalangan ulama usul fikih. Mayoritas ulama usul fikih berpendapat bahwa tidak boleh mempertentangkan dalil qat 'î dengan dalil żannî. Menurut ulama ini, selamanya dalil qat' $\hat{\imath}$ itu harus lebih diutamakan dari dalil żannî. Sebab, dalil qat ‘̂́ itu sifatnya pasti sedangkan żannî masih bersifat bisa berubah. Di antara ulama usul fikih yang berpendapat bahwa dalil qat' $\hat{\imath}$ harus didahulukan dari dalil $\dot{z} a n n \hat{\imath}$ adalah al-Asnawî. Menurut beliau, tidak boleh memperhadapkan dalil qat ' $\hat{\imath}$ dengan dalil żannî, sebab dalil qaț ' $\hat{\imath}$ selamanya harus didahulukan dari dalil żannî.

Ibn al-Hâjjib dalam salah satu bukunya: Mukhtașar, menyatakan bahwa tidak ada pertentangan antara dalil qat 'î dengan dalil $\dot{z} a n n \hat{\imath}$, sebab dalil żanni akan gugur dengan sendirinya jika ada dalil qat ' $\hat{\imath}$. Menurut asySyaukânî, pertentangan tidak akan terjadi, bila salah satu dalil bersifat qat 'î dan dalil lainnya bersifat żannî karena dalil $\dot{z} a n n \hat{\imath}$ akan dengan sendirinya menjadi gugur bila dihadapkan pada dalil qat 'î. Pandangan yang sama juga dikemukan oleh al-Âmidî dalam karyanya al-Ihkâm. Menurutnya, tidak ada pertentangan antara dalil qat 'î dengan dalil żannî, oleh karena itu, tidak boleh dilakukan tarjîh antara keduanya. Sebab, kata alÂmidî, tarjîh itu dapat dilakukan pada dua dalil yang bertentangan tetapi tidak pada dalil qat' 'î dengan dalil żannî karena tidak mungkin dalil qat ' $^{\prime} \hat{~ d e n g a n ~ d a l i l ~ y a n g ~ s a h i h . ~}{ }^{6}$

\footnotetext{
'Asy-Syaukânî, Irsyâd Fuḥ̂l ilâ Tahqî̀ min 'Ilm al-Ușûl (Surabaya: Penerbit Aḥmad Nahban, t.t), hlm. 273.

${ }^{2}$ Muhammad Wafâ, Ta'aruḍ al-Adillah asy-Syar'iyyah min al-Kitâb wa as-Sunnah wa at-Tarjị̂hu Bainahâ, terjemahan Muslich (Bangil: al-Izzah, 2001), hlm. 179.

${ }^{3}$ Asy-Syaukânî, Irsyâd Fuhûl, hlm. 273.

4‘Alî Ḥasaballah, Ușûl at-Tasyrî̀‘ al-Islâmî (Mesir: Dâr al-Ma‘ârif, 1964), cet. Ke-3, hlm. 322.

${ }^{5}$ Al-Asnawî, Syarh al-Asnawî Nihâyah al-Saul Syarh Minhâj al-Wuṣ̂l ilâ 'Ilm al-Uș̂ul al-Baiḍ̂wî (Kairo: Maktabah Muhammad 'Alî Șabih, t.t), Juz 3, hlm. 155.
} 
Berbeda dengan ahli usul fikih di atas, arRâzî berpendapat bahwa ta 'âruḍ al-adillah dapat saja terjadi pada dalil qaț 'î dengan dalil $\dot{z} a n n \hat{\imath}$. Hal demikian dapat terjadi kalau yang qat' $\hat{\imath}$ datang lebih dahulu dari dalil żannî sehingga sangat dimungkinkan yang datang kemudian dalam hal ini dalil żannî lebih diamalkan dari dalil qat 'î. Hal ini terjadi, kalau dalil yang bersifat żannî ini memang ada penjelasan kepastian tentang datangnya lebih kemudian. Sebaliknya, jika dalil yang bersifat żannî tersebut tidak ada penjelasan yang pasti tentang kedatangannya lebih kemudian dari dalil yang bersifat qat ' $\hat{\imath}$ maka dalam konteks demikian yang diamalkan atau didahulukan adalah dalil yang bersifat qat ' ${ }^{i}$. . Jika memang adanya kepastian bahwa dalil yang bersifat żannî datang lebih kemudian dari dalil qat' $\hat{\imath}$ maka penyelesaiannya tidak melalui tarjịh tetapi melalui an-naskh wa almansûkh.

Senada dengan ar-Râzî, Kamâl b Hammâm, salah satu ulama usul fikih dari mazhab Hanafiyyah berpendapat bahwa ta 'ârud al-adillah dapat saja terjadi antara dalil qat ' $\hat{\imath}$ dengan dalil żannî. Menurut beliau, sesungguhnya tidak ada persyaratan adanya kesamaan kekuatan dalam dua dalil yang saling bertentangan. Sebab, pendapat yang mensyaratkan adanya kesamaan kekuatan dalam dua dalil yang saling bertolakbelakang dari sisi hukumnya itu didasarkan pada pendapat yang mengatakan bahwa ta'ârud al-adillah terjadi secara hakiki. Padahal ta'âruḍ al-adillah itu hanya pada dataran lahiriyah, di mana diketahui adanya ta 'ârud al-adillah hanya oleh ulama (mujtahid) saja buka terjadi secara hakiki. ${ }^{8}$

Kedua, antara dua dalil qat 'î. Mungkinkah ada dua dalil qat ' $\hat{\imath}$ yang saling bertentangan? Asy-Syaukânî, dalam bukunya Irsyâd al-Fuhûl, berpendapat bahwa tidak mungkin terjadi pertentangan antara dua dalil qat '⿳⺈, baik keduanya sama-sama berbentuk 'aqli maupun naqli. Pendapat senada juga dikemukakan oleh al-Baidâwî, al-Syairazî, Ibn Subkhî dan al-Âmidî. ${ }^{9}$ Memperhatikan pendapat-pendapat para ahli usul fikih ini, aș-Șan'ânî, salah seorang ahli fikih mazhab Syâfi'î berkesimpulan bahwa pendapat para ahli usul fikih tersebut merupakan pendapat mayoritas ulama. ${ }^{10}$

Ketiga, ta'âruḍ al-adillah antara dua dalil żanni. Ta 'âruḍ al-adillah di sini dapat terjadi karena secara zâhir dan hakiki dari dua dalil itu sendiri. Untuk terjadinya ta 'âruḍ aladillah secara zâhir, Asnawî, dalam bukunya Syarh al-Asnawî, menyatakan bahwa ta 'âruḍ al-adillah sangat mungkin terjadi antara dua dalil żannî dalam pandangan seorang mujtahid. "I Senada dengan Asnawî, Ibn alSubkî menyatakan bahwa ta 'ârud al-adillah antara dua dalil żannî dalam pandangan seorang mujtahid itu memang benar adanya. ${ }^{12}$ Mengomentari adanya ta'ârud al-adillah antara dua dalil żannî, seperti dikemukakan oleh para ahli usul fikih tersebut, al-Jalâl alDîn al-Mahallî, berpendapat bahwa ta 'âruḍ al-adillah yang demikian itu benar-benar terjadi. ${ }^{13}$

Sedangkan terjadinya ta'ârud aladillah pada dua dalil żannî secara hakiki, masih menjadi silang pendapat para ulama usul fikih. Setidaknya, silang pendapat ini dapat dikelompokkan menjadi dua arus. Arus pertama, pendapat yang mengatakan bahwa terjadinya pertentangan secara hakiki atas dua dalil żannî adalah benar adanya. Pendapat ini, seperti dilaporkan oleh Muhammad Wafâ, dipegangi oleh alÂmidî, al-Baqillanî, Abû 'Alî al-Juba'î, Abû Hâsyim, Ibn Hâjib, al-Asnawî, asy-Syaukânî, al-Mawardî, ar-Rauyanî. Pertentangan itu bisa saja terjadi jika kedudukan dua dalil

\footnotetext{
${ }^{6} \mathrm{Al}$-Âmidî, al-Iḥkâm fî̀ Ușûl al-Ahkâm, hlm. 242.

${ }^{7}$ Ar-Râzî, Al-Mahsul, Juz 2, hlm. 547-548.

${ }^{8}$ Kamâl b Hammâm, al-Taqrîr wa al-Tahbîr Syarh Tahrîr (Kairo: Maṭba'ah al-Amîriyah Bulaq, 1316), Juz 3, hlm. 3.

${ }^{9}$ Muhạmmad Wafâ, Ta âruḍ al-Adillah, hlm. 41.

${ }^{10} A s ̦$-Ṣan'ânî, Ijâbah as-Sâil Syarh Bugyah al- 'Amal, Tahqị̂ Ḥusain Aḥmad Siyagî dan Hasan Muhammad Maqbûlî (Beirut: Muassasah ar-Risâlah, 1988), hlm. 417.

${ }^{11}$ Syarh al-Asnawî, Juz 3, hlm. 151.

${ }^{12}$ Al-Ibhâj, Syarh al-Manhaj, Juz, hlm. 213.

${ }^{13}$ Hasyiyah al-Anhâr, Juz 2, hlm. 401.
} 
itu memang sejajar, bukan satu dalil lebih unggul kedudukannya atas dalil yang lain. ${ }^{14}$ Arus kedua, pendapat yang mengatakan bahwa pertentangan secara hakiki tidak akan terjadi antara dua dalil żannî. Menurut kelompok ini, seandainya ada dua dalil żannî yang saling bertentangan, maka mungkin para mujtahid dapat mengamalkan keduaduanya, atau tidak mengamalkan keduanya, atau mengamalkan salah satunya. ${ }^{15}$ Seperti dilaporkan oleh Muḥammad Wafâ, pendapat ini dipegangi oleh Aḥmad dan Abû Ḥasan alKurkhî dan sekelompok ulama Syâfi'iyyah. Mengomentari pendapat-pendapat ini, Ibn Subkî berkesimpulan bahwa pendapat ini adalah pendapat yang benar. ${ }^{16}$

Ada perbedaan antara dalil al-Quran dan as-Sunnah al-Maqbûlah dalam kaitannya dengan pilihan tarjîh. Kalau ada dua dalil, misalnya ayat al-Quran dengan ayat alQuran yang saling bertentangan, maka hal demikian bukan bertentangan secara hakiki sehingga salah satu yang harus dihilangkan, sebab pada al-Quran titik perbedaannya bukan pada hakiki dari ayat tetapi pada pemahaman manusia atas ayat itu sendiri. Dengan kata lain, dalil yang kontradiksi ini tidak menyentuh al-Quran karena tidak mungkin Allah berfirman dalam dua hal yang berbeda. Kalau pun terjadi pada ayat-ayat alQuran, maka kontradiksinya itu bukan secara lahiriyah karena adanya ragam pemahaman. Berbeda dengan al-Quran, kontradiksi dapat terjadi pada dalil as-Sunnah al-Maqbûlah atau pendapat mujtahid, baik secara lahiriyah maupun secara hakiki sehingga dapat dilakukan tarjîh padanya. Dalam melakukan tarjîh kepada hadis, maka yang dilakukan adalah pada aspek sanad, matan, maksud, faktor-faktor ekstern dan aspek lainnya. Jadi, hadis sangat mungkin dipahami secara lahir maupun hakikinya saling bertentangan satu dengan lainnya sehingga dilakukan tarjîh padanya.

Asy-Syaukânî dalam bukunya Irsyâd al-Fuhûul ilâ Tahqî̀q min 'Ilm al-Ușûl memberikan pedoman kepada para mujtahid bila menemui dua dalil yang dianggap kontradiktif yang eksekusinya dilakukan melalui pilihan tarjîh, yaitu dengan syaratsyarat sebagai berikut:

1. Dalil-dalil itu sama dalam ketetapan (śubût) nya sehingga karena itu tidak ada pertentangan yang mengharuskan tarjîh antara al-Quran dengan hadis ahad.

2. Dalil-dalil yang bertentangan itu samasama memiliki kekuatan dari sisi hukumnya.

3. Hukum permasalahan harus sama serta bersamaan pula waktu, objek dan seginya. Oleh karena itu, tidak bisa dianggap ada pertentangan sehingga harus dilakukan tarjịh, misalnya, antara larangan berjual beli waktu ażân dengan kebolehan berjual beli di luar waktu ażân. ${ }^{17}$

Berbeda dengan asy-Syaukânî, Muhammad Wafâ, menyebutkan syaratsyarat dalam melakukan ta 'ârud al-adillah sebagai berikut:

1. Hukum yang ditetapkan oleh kedua dalil tersebut saling bertentangan seperti halal dengan haram, wajib dengan tidak wajib, maka yang dipilih adalah yang meniadakan. Karena bila tidak saling bertentangan, maka tidak ada pertentangan.

2. Objek kedua hukum yang saling bertentangan tersebut sama. Adapun objeknya berbeda-beda, maka tidak ada pertentangan.

3. Masa atau waktu berlakunya hukum yang saling bertentangan tersebut sama. Apabila masa atau waktunya berbeda, maka tidak ada pertentangan.

4. Hubungan kedua dalil yang saling bertentangan tersebut sama. Karena mungkin saja dua hukum yang saling bertentangan tersebut sama dalam objek dan waktu, namun hubungannya berbeda.

\footnotetext{
${ }^{14}$ Muhammad Wafâ, Ta âruḍ al-Adillah, hlm. 47-48. Ibid., hlm. 49-50.

${ }^{15}$ Ibid., hlm. 49.

${ }^{16}$ Asy-Syaukânî, Irsyâd al-Fuhûl, hlm. 273.

${ }^{17}$ Muhammad Wafâ, Ta 'âruḍ al-adillah, hlm. 68-73.
} 
5. Kedudukan kedua dalil yang saling bertentangan tersebut sama, baik dari segi asal maupun petunjuk dalilnya. ${ }^{18}$

Dalam men-tarjîh hadis yang saling kontradiktif, maka aspek yang dilakukan padanya adalah aspek sanad dan matan. Menurut Mukhtar Yahya dan Fatkhurrahman, dalam men-tarjîh aspek sanad, ada hal-hal yang perlu dilakukan, yaitu:

1. Mendahulukan hadis yang diriwayatkan oleh perawi yang lebih śiqah daripada perawi yang kurang śiqah.

2. Mendahulukan periwayatan orang menerima hadis atau mengetahui peristiwa secara langsung daripada orang yang menerimanya tidak langsung.

3. Mendahulukan periwayatan orang banyak bergaul dengan Nabi daripada orang yang tidak banyak bergaul.

4. Mendahulukan periwayatan orang yang masih kuat hafalannya daripada orang yang sudah rusak hafalannya lantaran lanjut usia.

5. Mendahulukan periwayatan sahabat besar daripada periwayatan sahabat kecil.

6. Mendahulukan hadis yang di-takhrij-kan oleh al-Bukhârî dan Muslim daripada yang di-takhrij-kan oleh selainnya.

7. Mendahulukan hadis yang banyak diriwayatkan orang. ${ }^{19}$

Dalam ilmu usul fikih, tarjîh tidak semata digunakan untuk melakukan pelacakan atas dalil-dalil yang secara lahir nampak bertentangan sehingga harus dicari atau ditentukan mana yang lebih râjiḥ (kuat) dan mana yang marjûh, tetapi tarjîh juga digunakan untuk menentukan atas qawl atau pendapat para ulama atau mazhab yang argumen mereka saling bertentangan. Kegiatan tarjîh dalam konteks ini juga sama seperti yang dilakukan atas dalil-dalil yang kontradiktif satu dengan lainnya seperti dikemukakan sebelumnya, yaitu melakukan pencarian secara mendalam mana yang lebih râjih dilihat dari kedekatannya dengan sumber ajaran Islam dan ketepatan metode penyimpulan sesuai dengan kaidah usul fikih dan kaidah lainnya.

Bila dicermati kegiatan me-râjiḥ atas qawl ulama atau mazhab, maka kegiatan tarjîh termasuk tingkatan ijtihad paling rendah dibanding tingkatan ijtihad lainnya. Dalam usul fikih, ada beberapa tingkatan ijtihad. Menurut Abû Zahrah, ${ }^{20}$ dalam kaitannya dengan kegiatan ijtihad terdapat beberapa tingkatan secara hirarkhis, yaitu:

1. Ijtihad mutlak.

Menurut Abû Zahrah, ijtihad mutlak ini merupakan ijtihad paling tinggi dibanding ijtihad lainnya. Rangking ini terkait dengan mujtahid yang melakukan ijtihad, di mana mereka memiliki persyaratan metodologi yang mandiri. Dalam melakukan ijtihad, ia tidak terikat kepada orang lain, baik dari aspek $u s ̦ u l$ maupun fur $\hat{u}^{\prime}$. Mujtahid tingkatan ini dalam melakukan ijtihadnya, beristidlâl langsung kepada al-Quran dan al-Sunnah alMaqbûlah sesuai dengan manhaj-nya sendiri. Dengan kata lain, mereka memiliki manhaj secara mandiri dalam memahami al-Quran dan al-Sunnah al-Maqbûlah serta metode lainnya (dalam uș̂ul dan furû̀). Mujtahid tingkatan ini contohnya Abû Hanîfah, Mâlik, Syâfîî dan Ạ̣mad b Hanbal. Mereka ini dikenal sebagai penggagas empat mazhab, yaitu mazhab Hanafî, Mâlikî, Syâfi'î dan Hanbalî.

2. Ijtihad muntasib.

Ijtihad muntasib adalah ijtihad yang dilakukan seorang mujtahid dengan menggunakan metode, norma dan kaidahnya. Untuk menggali hukum dari sumbernya, mereka memakai sistem atau metode yang dipakai olehnya dan tidak menciptakan sendiri. Contoh ijtihad seperti ini dilakukan oleh murid-murid penggagas mazhab. ${ }^{21}$

\footnotetext{
${ }^{18}$ Muhtar Yahya dan Fathurrahman, Dasar-dasar Pembinaan Hukum Fikih Islami (Bandung: al-Ma'arif, 1993), hlm. 470474.

${ }^{19}$ Dikutip dari Ibrahim Hosen, “Taqlid dan Ijtihad: beberapa Pengertian Dasar”, dalam Budy Munawar-Rahman, Kontekstualisasi Doktrin Islam dalam Sejarah (Jakarta: Paramadina, 2006), hlm. 324.

${ }^{20} \mathrm{Ibid}$., hlm. 325.

${ }^{21}$ Ibid.
} 
3. Ijtihad mazhab.

Yaitu ijtihad yang dilakukan seorang mujtahid dalam lingkungan mazhabnya. Pada prinsipnya mereka mengikuti norma, kaidah istinbatnya. Ijtihad mereka hanya berkisar pada masalah-masalah yang memang belum diijtihadi oleh pendahulunya, men-takhrîjkan pendapat dan menyeleksi beberapa pendapat yang dinukil darinya, mana yang sahih dan mana yang lemah. Contohnya dilakukan Ghazali. ${ }^{22}$

4. Ijtihad tarjîh.

Yaitu ijtihad yang dilakukan dengan cara mentarjih dari beberapa pendapat yang ada baik dalam satu lingkungan mazhab tertentu maupun dari berbagai mazhab yang ada dengan memilih mana di antara pendapat itu yang paling kuat dalilnya atau mana yang paling sesuai dengan kemaslahatan sesuai dengan zamannya. ${ }^{23}$

Indikator perumusan suatu pendapat dengan menggunakan metode tarjih adalah pengungkapan pendapat-pendapat dengan argumentasi masing-masing lalu dari sekalian pendapat itu ditelusuri argument masing-masing. Setelah itu dipilih argument yang paling kuat di antara argument-argumen yang ada. Contoh penggunaan tarjih senagai metode, seperti yang dipakai Majelis Tarjih saat memutuskan suatu hukum.

\section{Contoh Shalat Id di Lapangan}

Majelis Tarjih dan Tajdid (selanjutnya ditulis Tarjih) pernah ditanya tentang tempat pelaksanaan shalat id. ${ }^{24}$ Dalam menjawab masalah ini Tarjih menggunakan metode tarjih. Sebagaimana diketahui bahwa di tengah masyarakat Muslim Indonesia, dapat ditemukan dua tempat pelaksanaan shalat id, yaitu di lapangan dan di masjid. Variasi pendapat tentang tempat pelaksanakaan ini dapat ditemukan pada pendapat mazhab, yaitu, mazhab Hanafi, Maliki, Syafi'I, dan Hanbali.

Mazhab Hanafi, seperti dikutip oleh Tarjih, menganggap utama shalat id itu dilaksanakan di lapangan, dan makruh di masjid kecuali karena hujan. Mazhab Maliki berpendapat bahwa shalat id di lapangan sangat dianjurkan daripada shalat id di masjid. Sedangkan menurut mazhab Hanbali, disunnatkan melakukan shalat id di lapangan yang dekat dengan bangunan atau pemukinan. Berbeda dengan ketiga mazhab tersebut, mazhab Syafi'I berpendapat bahwa shalat id itu utama dilaksanakan masjid daripada di lapangan oleh karena di masjid adalah terjamin kebersihannya. ${ }^{25}$

Setelah mengemukakan pendapat empat mazhab, Tarjih memilih pendapat bahwa tempat pelaksanaan shalat id itu di lapangan. Pilihan Tarjih ini sama dengan pendapat mazhab Hanafi, Hanbali dan Maliki. Penguatan pendapat Tarjih ini didasarkan pada apa yang dilakukan oleh Nabi dan para sahabatnya yang melakukan shalat id di mushala, yaitu di pintu masuk kota Madinah di bagian Timur, atau di lapangan.

\section{Kesimpulan}

Dari uraian yang dijelaskan di muka dapat disimpulkan bahwa tarjih sebagai metode dalam memutuskan suatu masalah/ kasus adalah memilih atau menguatkan salah satu dalil atau pemikiran dari berbagai dalil atau pemikiran yang saling bertentangan (ta 'ârud al-adillah). Dalam studi ilmu ushul fiqh, tarjih ini merupakan solusi ketiga setelah metode al-jam'u wa taufíq dan nâsikh wa al-mansûkh. Para ulama usul fiqh telah memberikan berberapa persyaratan dalam menerapkan tarjih sebagai metode dalam merumuskan suatu masalah atau kasus. 


\section{Daftar Pustaka}

Asy-Syaukânî, Irsyâd Fuḥ̂l ilâ Taḥqîq min 'Ilm al-Uṣûl (Surabaya: Penerbit Aḥmad Nahban, t.t).

'Alî Ḥasaballah, Ușûl at-Tasyrî' al-Islâmî (Mesir: Dâr al-Ma'ârif, 1964), cet. Ke-3.

Ibrahim Hosen, "Taqlid dan Ijtihad: beberapa Pengertian Dasar", dalam Budy MunawarRahman, Kontekstualisasi Doktrin Islam dalam Sejarah (Jakarta: Paramadina, 2006).

Kamâl b Hammâm, al-Taqrîr wa al-Taḥbîr Syarh Tahrîr (Kairo: Maṭba'ah al-Amîriyah Bulaq, 1316), Juz 3.

Muhammad Wafâ, Ta 'aruẹ al-Adillah asy-Syar 'iyyah min al-Kitâb wa as-Sunnah wa atTarjîhu Bainahâ, terjemahan Muslich (Bangil: al-Izzah, 2001).

Muhtar Yahya dan Fathurrahman, Dasar-dasar Pembinaan Hukum Fikih Islami (Bandung: al-Ma'arif, 1993).

Aṣ-Șan'ânî, Ijâbah as-Sâil Syarh Bugyah al- 'Amal, Tahqîq Husain Ahmad Siyagî dan Hasan Muḥammad Maqbûlî (Beirut: Muassasah ar-Risâlah, 1988), hlm. 417.

Al-Asnawî, Syarḥ al-Asnawî Nihâyah al-Saul Syarh Minhâj al-Wuṣ̂ul ilâ 'Ilm al-Uș̂ul alBaiḍ̂wî̀ (Kairo: Maktabah Muḥammad 'Alî Șabih, t.t), Juz 3.

Tim PP Muhammadiyah Majelis Tarjih, Tanya Jawab Agama (Yogyakarta: Suara Muhammadiyah, 2004), Jilid 3, Cet. III. 